\title{
PENGEMBANGAN MANAJEMEN SUMBER DAYA MANUSIA SEBAGAI SEBUAH KEUNGGULAN KOMPETITIF PADA INDUSTRI PARIWISATA DAN PERHOTELAN
}

\author{
Eko Lianto Rihardi \\ GoAcademica CRP, Bandung, Indonesia \\ Email: ekogprsoke@gmail.com
}

\begin{abstract}
Abstrak
Pariwisata dan perhotelan merupakan industri yang sangat bergantung kepada sumber daya terutama sumber daya manusia. Berbagai studi ilmiah menunjukkan bahwa kualitas sumber daya manusia di perusahaan pariwisata dan perhotelan secara langsung mempengaruhi daya saing dan kelangsungan hidup perusahaan-perusahaan tersebut di pasar. Perhatian khusus dalam penelitian ini ditujukan pada analisis karakteristik spesifik sumber daya manusia di industri perhotelan dan pariwisata, dan terutama kualitas pekerjaan dalam kegiatan ini. Banyak penulis menunjukkan aspek negatif dari pekerjaan di bidang pariwisata, seperti upah rendah, jam kerja diperpanjang, volume kerja tinggi, pekerjaan jangka pendek dan paruh waktu karena sifat musiman pekerjaan, dll. Oleh karena itu, pariwisata dan hotel perusahaan menghadapi masalah dalam merekrut dan mempertahankan tenaga kerja berkualitas tinggi, yang juga bergantung pada daya saing mereka di pasar pariwisata. Untuk alasan ini, dalam industri pariwisata dan perhotelan, peningkatan perhatian diberikan pada manajemen kualitas sumber daya manusia.
\end{abstract}

Kata Kunci : Manajemen Sumber daya Manusia, Keunggulan Kompettif, Pariwisata, Perhotelan.

Abstract

Tourism and hospitality are industries that are highly dependent on resources, especially human resources. Various scientific studies show that the quality of human resources in tourism and hospitality companies directly affects the competitiveness and viability of these companies in the market. Particular attention in this study is devoted to the analysis of the specific characteristics of human resources in the hotel and tourism industry, and especially the quality of work in these activities. Many authors point out the negative aspects of employment in tourism, such as low wages, extended working hours, high work volume, short-term and part-time jobs due to the seasonal nature of work, etc. Therefore, tourism and hotel companies face problems in recruiting and retaining high quality workforce, who also depend on their competitiveness in the tourism market. For this reason, in the tourism and hospitality industry, increasing attention is paid to the quality management of human resources.

Keywords: Human Resource Management, Competitive Advantage, Tourism, Hospitality

\section{A. PENDAHULUAN}

Pariwisata adalah salah satu sektor ekonomi terbesar di dunia dan salah satu sumber utama pendapatan asing dan penghasil lapangan kerja bagi banyak negara (Utama, 2015). Menurut Organisasi Pariwisata Dunia, tercatat sebanyak 1.326 juta kunjungan wisatawan mancanegara ke destinasi di seluruh dunia pada tahun 2018 dan penerimaan pariwisata internasional mencapai US 
\$ 1.340 miliar (UNWTO, 2019). Pertumbuhan sektor pariwisata relevan dengan pertumbuhan ekonomi nasional. Pariwisata mendorong pertumbuhan sejumlah besar perusahaan yang pertumbuhan lapangan kerjanya disediakan melalui kegiatan yang berhubungan dengan industri pariwisata (Yoety, 2008).

Pariwisata merupakan kegiatan padat karya yang artinya membutuhkan banyak tenaga kerja untuk kinerjanya. Ini adalah area tempat terciptanya jumlah pekerjaan terbesar (Sassongko \& Wijayati, 2018). Tahun 2017 tercatat 313.221 .000 orang yang bekerja dalam kegiatan ekonomi yang secara langsung dan tidak langsung terkait dengan pariwisata, atau 9,9\% dari total lapangan kerja. Pada 2017, Travel \& Tourism secara langsung mendukung 118.454 .000 pekerjaan $(3,8 \%$ dari total pekerjaan). Setiap 10 pekerjaan di dunia termasuk dalam aktivitas pariwisata (WTTC, 2018).

Dekade terakhir dalam pariwisata internasional dicirikan oleh keunggulan kompetitif yang dicapai perusahaan pariwisata dengan bantuan karyawan yang berpendidikan (Isdarmanto, 2020). Di bawah kondisi pasar pariwisata yang sangat kompetitif, kekuatan dasar setiap perusahaan pariwisata bukanlah peralatan teknis atau ruang, peralatan IT, atau jenis produk pariwisata - karena semuanya dapat diganti, dicerminkan, dan diubah. Kekuatan dasar setiap perusahaan pariwisata adalah sumber daya manusia Kepuasan tamu secara keseluruhan dengan tawaran wisata tergantung langsung pada kualitas layanan yang diberikan oleh pekerja pariwisata (Nurhajati, 2020).

Jarang ada kegiatan ekonomi yang sebagian besar bergantung pada sumber daya manusia, seperti pariwisata (Nurjaman, 2020). Meskipun hal ini juga dapat dikatakan berlaku untuk kegiatan tersier lainnya, yang ditandai dengan kontak penawar dengan pelanggan, dalam pariwisata, yang dengan benar membawa atribut tatap muka, peran besar dimainkan oleh tuan rumah yang menyediakan keramahtamahan kepada para tamu. Wisatawan yang tiba di suatu tempat tujuan wisata, tinggal di lingkungan yang tidak diketahui, dimana mereka mengharapkan tuan rumah memberikan perhatian yang besar dan memberikan akomodasi terbaik, makanan dan jasa wisata lainnya. Kualitas kunjungan turis yang bersifat sementara sangat bergantung pada keterlibatan, niat baik dan pendidikan karyawan (Vidianto, 2015).

Sumber daya manusia, oleh karena itu, merupakan faktor daya saing yang sangat penting dalam industri pariwisata dan hotel. Sumber daya manusia adalah salah satu sumber daya terpenting dari sebuah perusahaan pariwisata, yang secara langsung mempengaruhi daya saing dan kelangsungan hidupnya di pasar pariwisata (MUbarok dkk, 2020). Semua sumber daya di perusahaan pariwisata penting, tetapi sumber daya manusia adalah sumber daya yang menghubungkan semua sumber daya lain ke unit organisasi yang koheren. Hanya personel berkualitas tinggi yang dapat menanggapi tantangan yang ditimbulkan oleh lingkungan bisnis yang sangat kompetitif (Setiawan, 2015).

Untuk memperoleh dan mempertahankan salah satu keunggulan kompetitif yang telah diraih, perusahaan pariwisata harus terus mengembangkan pengetahuan, kreativitas, dan inovasi sumber daya manusia, karena perusahaan yang sukses di masa depan akan menjadi situs 
pengetahuan, kualitas, dan kemampuan yang menjadi hak mereka. selalu dapat merespons anomali pasar jangka pendek dengan mudah (Sulastri \& Uriawan, 2020)..

\section{B. METODE}

Metode yang digunakan dalam penulisan ini adalah metode penelitian kualitatif deskriptif karena ingin mendeskripsikan dan menjelaskan bagaimana manajemen sumber daya manusia sebagai salah satu faktor yang meningkatkan daya saing dalam industri pariwisata dan perhotelan. Penelitian ini berkaitan dengan aspek kualitas, nilai atau makna yang terkandung di balik fakta. Oleh karena itu, bentuk data yang digunakan bukan berupa angka, angka, skor atau nilai, rating atau frekuensi, yang biasanya dianalisis menggunakan perhitungan matematis atau statistik. Menjelaskan fenomena secara kualitatif secara mendalam melalui pengumpulan data secara mendalam (Creswell, 2015).

\section{HASIL DAN PEMBAHASAN}

\section{Karakteristik Sumber Daya Manusia}

Dalam semua kegiatan ekonomi, termasuk pariwisata, pekerjaan manusia memiliki peran dan signifikansi yang penting dan spesifik. Pariwisata terus beradaptasi dengan tren kontemporer di pasar pariwisata. Oleh karena itu, sumber daya manusia di bidang pariwisata melalui kehidupan, pekerjaan dan filosofi bisnis, pendidikan dan pekerjaan, berusaha untuk beradaptasi dengan meningkatnya permintaan pengguna jasa pariwisata. Sumber daya manusia dalam pariwisata tidak hanya mencakup mereka yang bekerja dalam pariwisata, tetapi juga nilai total, kualitas, kemampuan dan keterampilan yang berguna, pengetahuan dan pengalaman yang tersedia, ide dan kreasi yang mungkin, tingkat motivasi dan minat dalam mencapai tujuan bisnis (Lee-Ross \& Pryce, 2010).

Namun, perusahaan dan pengelola pariwisata menghadapi masalah dalam perekrutan, pengembangan dan pemeliharaan tenaga kerja yang kompeten dan termotivasi, yang difokuskan pada penyediaan layanan berkualitas kepada konsumen yang semakin menuntut. Banyak penulis menunjukkan aspek negatif dari pekerjaan di bidang pariwisata, seperti upah rendah, jam kerja yang diperpanjang, volume kerja yang tinggi, pekerjaan jangka pendek dan paruh waktu karena sifat musiman pekerjaan, dll. Di satu sisi, pariwisata dan manajemen hotel menyediakan lingkungan kerja yang menarik dengan status tinggi, upah dan kondisi kerja yang kompetitif. Ada permintaan tinggi di antara angkatan kerja, sedangkan fluktuasi karyawan di sektor ini rendah. Di sisi lain kondisi buruk, upah rendah, fluktuasi karyawan yang tinggi, masalah dalam melibatkan orang-orang yang memenuhi syarat di beberapa bidang utama, status yang buruk dan praktis kurangnya profesionalisme (Setiawan, 2016).

Sejumlah besar penulis menganggap masalah kualitas pekerjaan di pariwisata. Ada empat keyakinan umum yang dianut tentang pekerjaan pariwisata, yaitu : pariwisata menghasilkan pekerjaan terutama dengan keterampilan rendah; pariwisata menghasilkan pekerjaan bergaji 
rendah; Pekerjaan pariwisata tidak menawarkan kepuasan kerja tingkat tinggi; pariwisata menawarkan kesempatan terbatas untuk kemajuan bagi penduduk lokal (Bagiastuti, 2017).

Sebagian besar pegawai pariwisata tidak berpendidikan memadai. Mereka kebanyakan tamat SMA, sedangkan pendidikan tersier jarang. Kedua, pekerjaan jangka pendek dan paruh waktu biasa terjadi karena sifat pekerjaan musiman. Gaji dalam banyak kasus rendah dan jam kerja tidak menyenangkan. Ketiga, sulit untuk membangun karir di bidang pariwisata dalam arti kata tradisional. Karena semua alasan ini, fluktuasi pekerja di sini jauh lebih tinggi daripada di aktivitas lain. Semua ini mempengaruhi tingkat kualitas layanan, karena tidak mungkin seseorang yang tidak berkomitmen pada suatu perusahaan dalam jangka panjang akan memiliki motivasi, pengetahuan dan pengalaman untuk berkontribusi pada proses pengembangan suatu perusahaan di bidang pariwisata (Tj, 2019). Di sisi lain, ini bisa menjadi keuntungan. Fluktuasi tenaga kerja menyebabkan pertukaran karyawan di antara perusahaan pariwisata di beberapa daerah, yang dapat meningkatkan transfer pengetahuan (Nathalia, 2010).

Berikut ini merupakan ciri-ciri dasar yang menjadi ciri masalah karyawan yang bergerak di industri pariwisata yaitu:

- Persentase yang tinggi dari pekerjaan angkatan kerja perempuan. Dalam industri perhotelan, pekerjaan rumah tangga, layanan makanan dan minuman, pekerjaan dapur, pekerjaan resepsionis, kasir, administrasi, dll. Dilakukan terutama oleh tenaga kerja wanita. Situasi serupa terjadi di agen pariwisata, di mana karyawan perempuan menjadi penentu.

- Partisipasi tinggi dari tenaga kerja tidak terampil. Ada berbagai macam pekerjaan di sektor pariwisata yang tidak memerlukan kualifikasi khusus.

- Kebutuhan tenaga kerja musiman yang banyak. Tenaga kerja musiman yang tidak direkrut dari penduduk lokal, tetapi dari tempat lain, bahkan negara, dapat mempengaruhi terciptanya permasalahan sosial di suatu daerah tujuan wisata.

Dalam hal jam kerja yang tidak menguntungkan, untuk pekerjaan tertentu, terutama di hotel-hotel sejenis rumah kos, jam kerja yang tidak merata atau jam kerja split-shift merupakan ciri khasnya. Tidak jarang karyawan yang sama terlibat sesekali bahkan tiga kali dalam sehari (terkait dengan waktu menyiapkan dan menyajikan makanan utama). Jenis keterlibatan ini menyebabkan lebih banyak kelelahan, sekaligus mengurangi waktu yang dihabiskan untuk liburan, sehingga memperumit kondisi kerja dan memengaruhi karyawan secara destimulatif. Banyak keterlibatan karyawan selama hari kerja merupakan karakteristik hotel dengan bisnis musiman, yaitu tenaga kerja musiman (Tamengkel \& Rumawas, 2020).

Faktanya adalah bahwa kualitas layanan yang ditawarkan bergantung pada kualitas karyawan, dan karenanya merupakan keunggulan kompetitif dari sebuah perusahaan pariwisata (Walls, 2021). Namun, perlu diingat bahwa tidak semua karyawan di perusahaan memiliki posisi yang sama dalam kaitannya dengan wisatawan dan tidak semuanya memiliki dampak yang sama terhadap wisatawan. Karyawan di bidang pariwisata dapat dibagi menjadi : 
- Karyawan yang menyediakan layanan dan langsung berhubungan dengan wisatawan, yang kebaikan, kesegeraan, dan profesionalismenya bergantung pada kepuasan wisatawan terhadap layanan yang ditawarkan;

- Karyawan yang mengeksplorasi keinginan dan kebutuhan wisatawan, dan yang karenanya menciptakan ide dan menciptakan layanan di bidang pariwisata.

Kontak yang paling sering dengan wisatawan diberikan oleh pekerja di loket di pusat info, agen wisata, resepsi hotel, pemandu wisata, pengikut, animator, pelayan, bartender, dll. Karyawan ini mewakili seluruh perusahaan, memberikan kesan pertama dan sangat sering. adalah satusatunya yang memengaruhi wisatawan, yang menjelaskan layanan tersebut dan akhirnya menjualnya. Dari peran penting karyawan ini, muncul kebutuhan bahwa mereka harus diuji dan dipilih secara khusus, untuk memiliki posisi khusus di perusahaan dan diberi penghargaan secara teratur). Personel yang kurang termotivasi dan tidak berkualifikasi tidak akan dapat memberikan layanan yang berkualitas. Tantangan nyata dalam mengelola sumber daya manusia di bidang pariwisata adalah rekrutmen dan retensi pekerja dengan keterampilan, pengetahuan, dan sikap yang sebenarnya terhadap pekerjaan tersebut.

\section{Manajemen Sumber Daya Manusia}

Manajemen Sumber Daya Manusia mengacu pada manajemen orang dan interaksi mereka dalam perusahaan. Tujuannya agar setiap perusahaan menggunakan kemampuan karyawannya dengan cara yang benar. Terlepas dari apakah itu bisnis multinasional atau keluarga, perlu menemukan cara terbaik untuk mengelola sumber daya manusia. Ini adalah proses pengembangan yang mencakup kegiatan seperti: perencanaan karyawan, seleksi dan pelatihan karyawan, hubungan karyawan, penghargaan, pengembangan karir, motivasi karyawan, dll (Sinambela, 2021).

Manajemen sumber daya manusia telah menjadi salah satu perhatian utama para manajer dan organisasi modern. Semakin banyak perusahaan mendasarkan keunggulan kompetitif mereka pada cara merekrut, memilih, memotivasi, memberi penghargaan, mempromosikan, mengembangkan, dan mendidik karyawan mereka. Nilai suatu perusahaan tidak lagi dinyatakan hanya dalam pendapatan tahunan dan indikator keuangan lainnya, tetapi juga dalam kualitas karyawannya. Pada abad ke-21, persaingan antar perusahaan telah meluas dari pasar produk ke pasar tenaga kerja. Perusahaan-perusahaan yang berhasil mengenali perjuangan untuk sumber daya manusia ini tepat waktu sekarang adalah yang paling sukses di bidangnya (Udan, 2002).

Filosofi bisnis "Karyawan Anda mewakili perusahaan Anda" dan "Klien adalah yang kedua, pertama adalah yang dipekerjakan" diterapkan oleh semakin banyak perusahaan di industri jasa. Alasannya adalah perusahaan telah menyadari bahwa karyawan mereka juga merupakan klien terbaik mereka. Jika resepsionis di sebuah hotel sedang dalam mood yang buruk, jika pelayan tidak ramah, dapat dipastikan wisatawan akan memperhatikan dan menjadi tidak puas dan mengubah hotel. Dengan kata lain, karyawan yang tidak puas tidak dapat memuaskan tamunya. Oleh karena itu, masalah kepuasan karyawan, motivasi dan komitmen mereka terhadap organisasi sangat penting dalam industri pariwisata dan perhotelan (Anugrah \& Sudarmayasa, 2017). 
Manajer Sumber Daya Manusia harus terus memantau dan mengantisipasi perubahan lingkungan internal dan eksternal agar dapat menanggapinya secara tepat waktu dan memadai. Oleh karena itu, mereka harus memiliki pendekatan kewirausahaan dan proaktif, itulah sebabnya manajemen sumber daya manusia yang semakin modern dijelaskan oleh atribut strategis (Tampubolon, 2016).

Berbeda dengan sektor ekonomi lainnya, sektor pariwisata dicirikan oleh kekhususan yang memiliki pengaruh langsung dan tidak langsung terhadap strategi pengelolaan sumber daya yaitu

- Dalam pariwisata, jasa penawar tunggal tidak dijual, melainkan satu paket jasa untuk berbagai pelaku pasar. Kualitas masing-masing individu bagian dari paket layanan ini secara signifikan mempengaruhi pembentukan sikap wisatawan terhadap kualitas produk secara keseluruhan. Oleh karena itu dibutuhkan keterampilan khusus dari tenaga pariwisata.

- Pariwisata merupakan kawasan yang membutuhkan pekerjaan yang intensif. Kualitas layanan wisata tergantung pada ketersediaan jumlah karyawan.

- Kualitas suatu produk pariwisata ditentukan oleh banyaknya pelaku pasar, artinya keterkaitan dengan sektor ekonomi dan kegiatan sosial lainnya sangat kuat.

- Dipekerjakan dalam pariwisata harus memiliki pengetahuan dasar tentang semua kegiatan yang terlibat dalam pembuatan produk wisata, dan dengan demikian menjamin kualitas keseluruhan produk. Tingkat keterkaitan yang tinggi dengan sektor lain membuka peluang besar untuk menciptakan produk pariwisata yang berkualitas.

- Sektor pariwisata membutuhkan karyawan dengan profil kualifikasi yang luas.

\section{Proses manajemen sumber daya manusia di bidang perhotelan dan pariwisata}

Perencanaan sumber daya manusia biasanya diartikan sebagai proses antisipasi dan penciptaan kepedulian terhadap pergerakan orang-orang di perusahaan, guna memastikan jumlah dan struktur karyawan yang diperlukan, serta pemanfaatannya secara optimal (Nurwulandari dkk, 2021). Dalam perencanaan sumber daya manusia, manajemen sumber daya manusia mempunyai tugas untuk mengantisipasi banyaknya pekerjaan dan eksekutif yang akan melakukan kegiatan bisnis dengan cara yang paling efisien. Perencanaan tenaga kerja adalah pembuatan rencana untuk mengisi lowongan masa depan di suatu perusahaan yang didasarkan pada prediksi lowongan dan memutuskan apakah pekerjaan tersebut akan diisi oleh kandidat yang sudah bekerja di suatu perusahaan atau di luar perusahaan (Riniwati, 2016).

Perekrutan personel melibatkan proses menarik kandidat yang memenuhi syarat untuk mengisi lowongan, yang akan dipilih oleh manajemen perusahaan paling tepat selama proses seleksi. Proses pencarian kandidat yang cocok dimulai dengan memasang iklan di dalam perusahaan (sumber internal) atau di luar perusahaan (sumber eksternal). Sumber daya perekrutan internal termasuk mengisi pekerjaan untuk pekerja yang sudah ada yang memiliki kualifikasi yang diperlukan untuk mengisi lowongan, sedangkan sumber eksternal paling sering: pasar tenaga kerja, 
agen tenaga kerja, lembaga pendidikan, iklan, dll. Sumber perekrutan eksternal adalah pilihan ketika suatu perusahaan tidak dapat merekrut dari sumber internal.

Pemilihan personel adalah prosedur di mana kandidat, yang paling memenuhi persyaratan pekerjaan, dipilih dengan menerapkan metode dan teknik yang telah ditetapkan dan standar untuk pekerjaan tertentu. Ini adalah proses memilih di antara pelamar yang terbaik dan paling kompeten untuk mengisi posisi yang kosong. Pada tahap ini, pelamar dianalisis (biografi, wawancara, tes, dll.), Kemampuan mereka untuk melaksanakan pekerjaan mereka, serta karakteristik pribadi mereka (apa yang memotivasi mereka, bagaimana mereka bertindak "di bawah tekanan", apa / prioritasnya, bagaimana dia berperilaku dengan orang, dll.) dan kesiapan untuk kerja tim. Proses ini melibatkan pengambilan keputusan, tidak hanya tentang kandidat, tetapi juga tentang hubungan kandidat dan tempat kerja, dengan mempertimbangkan pengetahuan, keterampilan, kemampuan, dan karakteristik lain yang diperlukan untuk melakukan pekerjaan itu. Tujuan dari pemilihan ini adalah untuk memilih "orang yang tepat" dan menempatkannya di posisi yang tepat (Kusworo \& Damanik, 2002).

Pengenalan lingkungan kerja dan sosialisasi merupakan fase pengenalan karyawan baru pada suatu perusahaan, karyawan lain, struktur organisasi dan aturannya. Pada tahap ini, perusahaan harus memainkan peran "tuan rumah yang baik" untuk melepaskan pekerja baru sesegera mungkin dari ketidaknyamanan dan ketakutan awal dan beradaptasi dengan lingkungan kerja baru secepat mungkin. Sangat penting bahwa pendatang baru diberikan bantuan untuk beradaptasi secara emosional dengan tempat kerja baru. Mereka harus diarahkan kepada siapa yang harus dihubungi sehubungan dengan pekerjaan yang mereka lakukan dan bagaimana peran mereka sesuai dengan keseluruhan perusahaan. Proses pengenalan ke tempat kerja dan sosialisasi biasanya digunakan untuk memperkenalkan pekerja baru pada pesan budaya apa yang diharapkan perusahaan dari mereka dan apa yang dapat mereka harapkan sebagai balasannya (Anin dkk, 2019).

Setelah memilih karyawan yang pengetahuannya akan diinvestasikan, sangat penting untuk menemukan jenis pelatihan dan pengembangan karyawan yang tepat. Upaya berinvestasi dalam pemilihan karyawan yang cermat tidak dengan sendirinya menjamin bahwa mereka akan efektif. Pelatihan karyawan melibatkan persiapan untuk pekerjaan atau keterampilan khusus. Ini kurang berorientasi pada kepribadian, tetapi lebih berorientasi pada pekerjaan. Pelatihan dianggap sebagai metode memperoleh keterampilan dan pengetahuan baru yang diperlukan untuk melakukan bisnis. Melalui pelatihan, baik pekerja baru maupun yang sudah ada, serta karyawan manajerial, lolos. Yang paling umum digunakan adalah bentuk pelatihan internal (pengajaran, rotasi pekerjaan, dll.) Dan bentuk eksternal pelatihan karyawan (kursus, seminar, pelatihan, pendidikan, dll.). Manfaat pelatihan sangat banyak: produktivitas meningkat, jumlah karyawan yang keluar dari perusahaan berkurang, gaji karyawan meningkat, motivasi dan kepuasan karyawan meningkat, serta komitmen mereka terhadap perusahaan. Semua jaringan hotel terkemuka menerapkan pelatihan. Bentuk pelatihan berbeda, tetapi jaringan hotel paling terkenal memperhatikan kesamaan yang menyiratkan adanya standar kerja yang kaku dan tepat dan norma yang ditentukan secara tepat 
untuk melakukan operasi kerja tertentu di dapur, di resepsi, dalam penjualan, dll. Perusahaan besar melihat pelatihan sebagai investasi di masa depan, dan bukan sebagai biaya.

Salah satu aktivitas yang paling rumit adalah menilai kinerja dan menentukan kompensasi karyawan, serta mengambil tindakan korektif jika karyawan tidak berada pada tingkat yang memuaskan (Wilis \& Nurwulandari, 2020). Evaluasi kinerja karyawan adalah proses pemantauan yang terorganisir dan berkelanjutan, evaluasi, bimbingan dan penyesuaian hasil dan perilaku kerja mereka untuk mencapai tujuan organisasi, dan berdasarkan kriteria yang sesuai, metode dan sistem penilaian (Idrus, 2018). Dengan kata lain, grading adalah suatu sistem evaluasi karyawan (permanen atau berkala), terkait dengan standar yang ditetapkan oleh perusahaan. Ini menetapkan pekerja yang membutuhkan pelatihan tambahan, dari mereka yang berhak mendapatkan penghargaan, bonus, dan promosi. Proses penilaian sangat penting untuk pengembangan karir. Dalam hal menentukan kompensasi, perusahaan paling sering menggunakan deskripsi pekerjaan dalam hal kualifikasi, pengetahuan, dan keterampilan yang diperlukan sebagai dasar pengenalan skala pembayaran.

Untuk meningkatkan produktivitas, sebagian besar perusahaan mengembangkan sistem penghargaan melalui stimulasi (misalnya penambahan gaji) dan tunjangan (misalnya liburan berbayar, beasiswa, asuransi jiwa dan kesehatan, partisipasi ekuitas, dll.). Semua ini bertujuan untuk memotivasi karyawan, menjaga yang terbaik dan meningkatkan loyalitas mereka kepada perusahaan. Loyalitas datang langsung dari kepuasan karyawan di tempat kerja dan menyiratkan saling menguntungkan bagi karyawan dan perusahaan (Bagiastuti, 2017).

Penempatan karyawan dalam perusahaan, melalui perbaikan, mutasi, degradasi dan pemecatan, merupakan aspek yang sangat penting dari manajemen sumber daya manusia. Langkah-langkah ini bersifat konsekuensial dan terkait langsung dengan kinerja karyawan, keterlibatan, komitmen, kemampuan, dll.

Pengembangan karir terkait dengan memperoleh pengetahuan, keterampilan dan kemampuan baru yang memungkinkan seseorang untuk mengambil pekerjaan baru yang lebih kompleks. Berbeda dengan pelatihan yang berorientasi pada pekerjaan, karir berorientasi pada individu dan potensi yang dimilikinya. Karir merupakan konsep yang menggabungkan kepentingan dan kebutuhan individu dan organisasi, karena minat dalam pengembangan karir tidak hanya oleh individu, tetapi juga oleh perusahaan. Pengembangan karir mencakup berbagai kegiatan yang dilakukan seseorang untuk meningkatkan pengetahuan dan keterampilannya dan mendapatkan posisi yang lebih baik di tempat kerja. Fakta bahwa kemungkinan peningkatan karir adalah salah satu faktor yang paling memotivasi karyawan hanya menekankan pentingnya fenomena ini bagi perusahaan modern.

\section{KESIMPULAN}

Pariwisata adalah suatu kegiatan bisnis di mana karyawan adalah mereka yang membuat perbedaan, yang "menandai" dan membedakan layanan wisata dari kompetisi, yaitu mereka menciptakan keunggulan komparatif dan merupakan satu-satunya sumber daya yang tidak dapat 
ditiru. Namun, pariwisata dan industri perhotelan telah menghadapi banyak tantangan selama bertahun-tahun dalam hal mengelola, mempertahankan, dan memotivasi sumber daya manusianya.Sayangnya, pekerjaan industri pariwisata dan perhotelan telah disebut-sebut sebagai stres tinggi dan gaji rendah, yang merupakan faktor-faktor yang bertentangan dengan motivasi karyawan dan komitmen organisasi. Oleh karena itu, manajemen sumber daya manusia telah menjadi salah satu perhatian utama perusahaan modern dan salah satu faktor kunci daya saing dalam industri pariwisata dan perhotelan. Manajemen Sumber Daya Manusia melibatkan berbagai aktivitas yang tujuan utamanya adalah menemukan dan melibatkan "orang yang tepat di tempat yang tepat" untuk mencapai operasi bisnis yang sukses melalui manajemen yang efisien dan koordinasi aktivitas karyawan. Manajemen Sumber Daya Manusia adalah fungsi manajemen tingkat atas di bawah tanggung jawab manajer puncak. Dengan demikian, ini termasuk keputusan dan prosedur manajemen yang secara langsung mempengaruhi semua sumber daya manusia perusahaan.

\section{DAFTAR PUSTAKA}

Amin, G., Rahmiati, F., Ismail, Y., Simatupang, T., Larso, D., \& Othman, N. (2019). Pengembangan Pariwisata di Jakarta dalam Perspektif Sumber Daya Manusia. Jurnal Pariwisata Indonesia, 2(2).

Anugrah, K., \& Sudarmayasa, I. W. (2017). Pembangunan Pariwisata Daerah Melalui Pengembangan Sumber Daya Manusia Di Gorontalo. Jurnal Master Pariwisata (Jumpa).

Bagiastuti, N. K. (2017). Sertifikasi Kompetensi sebagai Upaya Perlindungan Hukum bagi Tenaga Kerja Industri Pariwisata dalam Menyambut IATA. Soshum: Jurnal Sosial dan Humaniora, 4(2), 140.

Creswell, J. W. (2015). Penelitian Kualitatif \& Desain Riset: Memilih Diantara Lima Pendekatan. Yogyakarta: Pustaka Pelajar.

Idrus, S. (2018). Perspektif Sumber Daya Manusia Pariwisata di Era Revolusi Industri 4.0. Prosiding Sintesa, Hal, 587, 594.

Isdarmanto, I. (2020). Strategi Branding Pengembangan Industri Pariwisata 4.0 melalui Kompetitif Multimedia di Era Digital. Journal of Tourism and Creativity, 4(1), 1-20.

Kusworo, H. A., \& Damanik, J. (2002). Pengembangan SDM pariwisata daerah: Agenda kebijakan untuk pembuat kebijakan. Jurnal Ilmu Sosial dan Ilmu Politik, 6(1), 105-120.

Lee-Ross, D., \& Pryce, J. (2010). Human Resources and Tourism: Skills, Culture And Industry (Vol. 2). Channel View Publications.

Mubarok, N. W., Hidayatunisa, N. F., Rahayu, N., \& Nurbayanti, N. L. (2020). Analisis Sumber Daya Manusia (Sdm) Pt. Weha Transportasi Indonesia Tbk. AKSELERASI: Jurnal Ilmiah Nasional, 2(2), 114-122.

Nathalia, T. C. (2010). Prospek Pengembangan Karir Terhadap Intensi Turnover Karyawan pada Industri Perhotelan. Hospitour Volume I, (1).

Nurjaman, K., Mustajam, A., Syaifuddin, S., Lubis, Y., \& Abadi, Y. (2020). Meningkatkan Kinerja Perusahaan Dengan Menerapkan Konsep Manajemen Sumber Daya Manusia Strategik 
Dalam Menyongsong Persaingan Global. Komitmen: Jurnal Ilmiah Manajemen, 1(2), 7382.

Nurwulandari, A., Hasanudin, H., \& Melati, M. (2021). Market Reactions on Corporate Actions

in Growing and Nongrowing Energy Consuming Companies. International Journal of Energy Economics and Policy, 11(3), 290-295.

Riniwati, H. (2016). Manajemen Sumberdaya Manusia: Aktivitas Utama dan Pengembangan SDM. Universitas Brawijaya Press.

Sasongko, P., \& Wijayati, D. (2018). Analisis Penyerapan Tenaga Kerja Sektor Perhotelan dan Restoran di Kecamatan Pacet Kabupaten Mojokerto. BISMA (Bisnis dan Manajemen), 6(2), 106-113.

Setiawan, R. I. (2016). Pengembangan Sumber Daya Manusia di Bidang Pariwisata: Perspektif Potensi Wisata Daerah Berkembang. Jurnal Penelitian Manajemen Terapan (PENATARAN), 1(1), 23-35.

Sinambela, L. P. (2021). Manajemen Sumber Daya Manusia: Membangun Tim Kerja yang Solid untuk Meningkatkan Kinerja. Bumi Aksara.

Sulastri, L., \& Uriawan, W. (2020). Pengaruh Lingkungan Kerja, Motivasi Dan Efikasi Diri Terhadap Kinerja Pegawai Di Era Industri 4.0. Komitmen: Jurnal Ilmiah Manajemen, 1(1), 43-49.

Tamengkel, L., \& Rumawas, W. (2020). Analysis of Factors That Influence Employees Turnover Intention (Study of Starred Hotel Employees in North Sulawesi). JURNAL ADMINISTRASI BISNIS (JAB), 10(1), 32-40.

Tampubolon, H. (2016). Strategi Manajemen Sumber Daya Manusia Dan Perannya Dalam Pengembangan Keunggulan Bersaing. Jakarta: UKI.

Tj, H. W. (2019). Impact of Work Value Affecting Employee Job Satisfaction for Improving Organizational Performance. International Journal of Science and Society, 1(4), 88-96.

Udan, B. (2002). Pengaruh Praktek Manajemen Sumber Daya Manusia Terhadap Budaya Organisasi dan Kinerja Perusahaan(Doctoral dissertation, UNIVERSITAS AIRLANGGA).

UNWTO. (2019). Tourism Highlight 2018 Edition. Diambil dari https://www.eunwto.org/doi/pdf/10.18111/9789284419876 pada 26 Desember 2020.

Utama, I. G. B. R. (2015). Pengantar Industri Pariwisata. Deepublish.

Vidianto, F. (2015). Analisis Pengaruh Kualitas Layanan Jasa Wisata Terhadap Loyalitas Melalui Kepuasan Wisatawan Pada Obyek Wisata Bromo Probolinggo. Jember: Unej.

Walls, P. J. (2021). Investing In Human Capital: Achieving Organizational Competitiveness Through Gamification. ENDLESS: International Journal of Future Studies, 4(1), 1-7.

Wilis, R. A., \& Nurwulandari, A. (2020). The effect of E-Service Quality, E-Trust, Price and Brand Image Towards E-Satisfaction and Its Impact on E-Loyalty of Traveloka's Customer. Jurnal Ilmiah MEA (Manajemen, Ekonomi, \& Akuntansi), 4(3), 1061-1099.

WTTC. (2018). Travel and Tourism Economic Impact. Diambil dari https://www.wttc.org//media/files/reports/economic-impactresearch/regions-2018/world2018.pdf pada 26 Desember 2020. 
Yoety, O. A. (2008). Ekonomi Pariwisata: Introduksi, Informasi, dan Aplikasi. Penerbit Buku Kompas. 